\title{
Stringency of Non-Tariff Measures in Partner Countries: Perceptions of Malaysian Exporters
}

\author{
Arumugam Sithamparam ${ }^{a}$ \\ Evelyn S. Devadason ${ }^{b}$ \\ Santha Chenayah ${ }^{c}$ \\ University of Malaya
}

\begin{abstract}
National policymakers and trade negotiators lack a clear understanding on what non-tariff measures (NTMs) their exporters perceive as predominant impediments to trade. This paper therefore examines the stringency of NTMs, by NTM-type and partner country, from the perspective of Malaysian exporters. The information is compiled through a representative firm-level survey of 143 exporting companies, and interviews with firms of different sizes and sectors in manufacturing. The key findings of the study are that NTMs, specifically technical measures, are perceived to be stringent and pose challenges to small and medium firms, resource-based firms and firms with less exposure to international markets. The stringency of customs procedures and other formalities, more specifically, is found to be not just a concern when exporting to the advanced markets (US, EU and Japan), but is also singled out to be an issue in exporting to the ASEAN region. The disproportionate effects that NTMs pose on exporters suggest that specific assistance and focus be provided to the affected firms.
\end{abstract}

Keywords: Exporters, Malaysia, non-tariff measures, stringency of non-tariff measures JEL classification: F14, F23, F60

\section{Introduction}

Globally, there has been a rise in trade measures, other than tariffs, that are generally perceived as trade-restricting. Known as non-tariff measures (NTMs), ${ }^{1}$ it has been reported that on average, approximately 5,620 tariff lines of most countries are subject to at least one type of NTM, with technical measures accounting for 58.55 percent of the total affected tariff lines (Fugazza \& Maur, 2008). Recently, as high as 31,731 measures were identified at the World Trade Organization (WTO, 2012).

NTMs have indeed emerged as a major concern for exporters of developing economies for the following reasons. They lack the resources (infrastructure and capacities) $)^{2}$ to comply with the higher standards and regulations of the developed world (World Bank, 2005; UNCTAD, 2013), they lack information on product standards

a Faculty of Economics and Administration, University of Malaya, 50603 Kuala Lumpur, Malaysia. Email: gsarumuga@gmail.com

b Department of Economics, Faculty of Economics and Administration, University of Malaya, 50603 Kuala Lumpur, Malaysia. Email: evelyns@um.edu.my (Corresponding author)

c Department of Economics, Faculty of Economics and Administration, University of Malaya, 50603 Kuala Lumpur, Malaysia. Email: santha@um.edu.my

1 UNCTAD (2013) defines NTMs as "policy measures, other than ordinary custom tariffs, that can potentially have an economic effect on international trade in goods, changing quantities traded or prices or both."

2 Refers to production facilities for testing and certification; and scientific and technical know-how. 
and regulations of the advanced countries, and they are not able to participate effectively in dispute settlement procedures to justify that their measures match with the requirements imposed by developed countries. The major issue for exporters relates to the compliance costs. For example, Jakubiak, Maliszewska, Orlova, Rokicka and Varyschuk (2006) estimated that 3.85 percent of production costs of Ukrainian exporters was spent on compliance in 2005, while Wilson and Otsuki (2004) showed that the average costs for customs clearance was 6.95 percent of the total export value of firms surveyed in developing countries in 2002.

NTMs faced by the developing world are many, mainly in the form of technical barriers to trade (TBTs), sanitary and phytosanitary (SPS) regulations, packaging, labelling, labour and environmental standards, and testing and inspection (OECD, 2005). To gauge the impact of NTMs on exchanges, previous studies have largely focused on applying trade restrictiveness indices on NTMs. Likewise, existing empirical studies on NTMs in Malaysia are either confined to the measurement of simple average ad valorem equivalents of core non-tariff barriers (NTBs) (Kee, Nicita, \& Olarreaga, 2009) to quantify the effects of NTMs on export behaviour, or case studies to identify specific sectoral NTBs within Malaysia and partner countries (see Hanif, 2013; Rabiul, Shaharuddin, \& Chamhuri, 2010; Noor Aini, 2011). These studies do not provide any indication of the standards and regulations that are considered 'stringent' ${ }^{3}$ and thereby pose difficulties for exporters to meet those requirements to enter global markets. Further, the stringency of complying with a specific NTM may vary across export destinations, particularly those NTMs found in developed markets. Consequently, information shortcomings prevail on which types of NTMs are excessively stringent and which trading partners maintain the most burdensome NTMs. Survey findings, based on the perceptions of exporters, are therefore needed to show if NTMs or NTBs have constrained businesses in their ability to make inroads into foreign markets (see also OECD, 2003; World Bank, 2008).

The study therefore emphasises micro-level evidence, based on a firm-level survey, specially constructed to identify the stringency of NTMs in major export markets from the Malaysian perspective. This newly compiled data has the advantage of drawing on experiences of economic agents that are directly involved in exporting activities. Information on the stringency of specific NTMs, stringency of NTMs by export destinations and to which category of Malaysian exporters, will provide policy direction for the government to devise specific strategies or incentives targeting the affected exporters, and also guide trade negotiators to streamline ${ }^{4}$ specific NTMs through trade agreements to ensure that they facilitate trade in the interest of the exporters.

The paper is organised in the following manner. Section 2 reviews previous empirical work on the effects of NTMs on trade. Section 3 details the data compiled for the study and the empirical strategy for assessing the stringency of NTMs. Section 4 reports and discusses the findings. Section 5 concludes with some policy implications.

3 The stringency effect is the trade-reduction effect that is attributable to the increased cost of doing business due to the presence of NTMs (Cadot \& Ing, 2015).

4 To simplify complex regulations and align them with established international standards. 


\section{The State of the Debate}

NTM measures can be private or public, and country-specific or harmonised. The WTO agreements deal with government introduced policies. The use of standards per se by member governments of the WTO is disciplined by the SPS and TBT agreements. ${ }^{5}$ Although both private and public standards represent market restrictions, private standards are generally considered to represent higher barriers to trade as they remain less transparent.

The SPS and TBT agreements per se, seek to promote harmonisation mainly to allow for exporters to reduce adaptation costs (related to product information and product compatibility) in importing markets (Maskus, Wilson, \& Otsuki, 2001; see also World Bank, 2003). Others opine that this may come at a cost, as exporters may lose differentiation or product variety in complying with a specific harmonised standard that they otherwise hold under a system of country-specific standards. The cost, however, is likely to be small or non-existent in the presence of network trade (WTO, 2005), as the benefits from economies of scale and network externalities often outweigh the costs of meeting the new harmonised standard. The above arguments suggest that while compatible standards bring advantages such as lower transaction costs and economies of scale in production, they also involve higher costs of compliance for firms in certain countries and result in reduced product variety. Economic theory therefore does not provide a clear cut answer whether the harmonisation of NTM measures in the form of standards and regulations enhances trade. The impact of NTMs on trade therefore remains unclear and begs an empirical enquiry.

Recent studies have clearly sought to quantify the effects of NTMs on trade, despite it being a daunting task given the vast information required to quantify heterogeneous standards and regulations across countries and over time. In addition, the required data is either not available or at times incomplete (Korinek, Melatos, \& Rau, 2008). The following discussion focuses on findings from previous work that have largely employed the gravity model and models of individual firm export decisions to examine the trade impact of NTMs.

Fontagne, von Kirchbach and Mimouni (2005) study realised a negative impact of environmental related measures (SPS and TBT) mainly on global trade of fresh and processed food relative to manufactured products. In terms of products, the negative impact is mainly on cut flowers, swine meat, vegetables, citrus, sugar, juices, wine, animal feed preparation and leather. Otsuki, Wilson and Sewadeh (2001) focused exclusively on Aflatoxin standards on food (mainly cereals, dried fruits, nuts and vegetables) trade between Africa and Europe (see Gebrehiwet, Ngqangweni and Kirsten, 2007 for exports between Africa and OECD) whilst lacovone (2005) extended on the effects of the same SPS standards on nuts exported from Latin America to Europe. All studies revealed negative effects of EU standards on trade flows of Africa and Latin America respectively.

5 The SPS Agreement covers all measures whose purpose is to protect human, animal or plant health. The TBT agreement covers all technical regulations, voluntary standards and conformity assessment procedures to ensure that regulations or standards are met. 
Mehta and George (2003) further highlighted the complexity and constraining market access of the SPS regime on processed food products for a large developing country like India. Their case studies revealed that stricter and shifting standards in developed countries have closed down some Indian plants whilst other exporters had to explore alternative markets. Likewise, Bao and Qiu (2012) focused on the trade impact of TBTs per se in China. Their study reported that the TBT effects on agricultural products and food processing in China - though found to be trade depressing - are relatively small compared to that of tariffs.

Chen, Otsuki and Wilson (2006) firm-level study showed that technical regulations reduce firms' export propensity of mainly domestically owned agricultural firms in developing countries. More importantly, their study revealed that market diversification is reduced when firms are negatively affected by standards, contrary to expectations. The reason given is that compliance with different standards across importing countries causes a firm to incur multiple fixed costs for entering into each market, which then leads to diseconomies of scale in the firm's production. The export market concentration of firms that are negatively affected by trade is found to be even more prevalent in the case of firms engaged in outsourcing, as compliance with standards in destination markets becomes more difficult when the inputs imported from various locations fail to meet the requirements imposed in the market of the final product. As such, the WTO (2005) asserted that in the presence of global networks in modern manufacturing, the adoption of an agreed standard facilitates the expansion of the market beyond national borders.

The macro and micro findings on the trade restricting impact of standards are however not unanimous. Swann, Temple and Shurmer (1996) found that idiosyncratic national standards encourage imports into the UK, thereby providing evidence against theoretical predictions of standards as barriers to imports. Similarly, Moenius (2004) found that importer specific (non-shared) standards in OECD countries promote trade, particularly for manufactured goods (see also Fontagne et al., 2005 for some nonfood items). The intuition for the above results is that importer standards provide information on both product requirements and consumer preferences (see also Maskus et al., 2001; Chen, Wilson, \& Otsuki, 2008) in import markets for potential exporters. Thus compliance costs associated with importer standards are more than offset by reduced information costs (see Athukorala and Jayasuriya, 2003, for similar reasoning on the trade facilitation possibilities of standards), of which the latter is of relative importance for exporters of manufactured goods that are largely heterogeneous. This theoretical explanation based on a signalling argument (see also Masakure, Henson, \& Cranfield, 2009), provides an alternative perspective to the mainstream literature on NTMs as barriers to trade.

Current literature frequently alludes to the signalling theory. A recent study by Chen et al. (2008) indicated that quality standards and labelling requirements are positively correlated with export volume and export scope (measured by number of export markets and products), whilst the opposite holds true for certification procedures. The explanation given for the former is that whilst quality standards reduce consumers' uncertainty and raise their willingness to pay for the product, design standards in turn ensure product compatibility and reduce coordination failures 
amongst producers. The same however cannot be said of the burdensome testing and certification procedures that are repetitive across markets. The study specifically sheds light on attaching importance to the type of technical regulation in importing countries when addressing the impact on exporting firms' performance in terms of economies of scale and scope.

The positive impact of NTMs on trade is also gaining wider empirical support with recognition of the competitive repositioning of some sectors facing stringent standards and regulations in importing countries. Henson and Jaffee (2004) illustrated the success of Kenyan exporters of fresh produce that have complied with the EU requirements and thus improved their access to these markets and the Peruvian exporters of asparagus who have reached the strict EurepGAP (Good Agricultural Practice, renamed as GlobalGAP) protocol and have benefited as a result. Disdier, Fekadu, Murillo and Wong (2008) based on their sectoral analysis of agricultural products reinforced the beneficial impact of SPS and TBT measures on trade. In a subsequent paper, Disdier, Fontagne and Mimouni (2008) pointed out that higher cost of compliance with SPS and TBT measures does not lead to loss of export markets for tropical product exporters in Ecuador, Costa Rica and Kenya. Likewise, Masakure et al. (2009) showed that certification to IS9000 benefited Pakistan exporters of textiles, leather and agro-food, whilst Jayasekhar and Kumar (2010) found evidence of a dual effect of stringent food safety regulations in the OECD on India's exports of seafood items.

The findings on the trade impact of NTMs obviously cannot be generalised given the dissimilarities in trade structure (product and market concentration) across countries, heterogeneity of NTMs across trading countries, and the lack of a unifying method to capture NTMs in various countries. Specifically, the studies surveyed above have a different approach to quantifying NTMs. Some studies have used constructed indicators to measure the restrictiveness of trade or severity of NTMs, whilst other studies have employed direct measures of a particular standard or regulation. Further, most studies have confined the effects of NTMs (more specifically SPS measures) on food and agricultural trade, taking into account that the developing world exports mainly agricultural products. More importantly, the main implication of the empirical literature is that NTMs may have an ambiguous effect on trade: they can have no impact on trade, they may facilitate trade or they may restrict trade (see also WTO, 2005; Schlueter, Rau, Wieck, Humphrey, Colen, \& Heckelei, 2009).

\section{Stringency of NTMs for Exporters}

\subsection{Primary Data Description}

The survey on Malaysian exporters was conducted between the period June and December 2014. The list of exporters' was sourced from the Malaysia External Trade Development Corporation (MATRADE). The MATRADE directory and website was used to identify 2,603 exporters ${ }^{6}$ in Malaysia from various sub-sectors. Of this list, only 781 exporting companies had complete information on their contact details. A total of 300

6 This does not include trading companies and service providers. 
questionnaires were distributed through an online survey platform to manufacturing exporters in Malaysia, comprising both resource-based and non-resource based firms. The total number of questionnaires used for the study is 143.

Prior to administering the survey, two strategies were adopted. First, the questionnaire was reviewed with the relevant government official, the Ministry of International Trade and Industry (MITI), to ensure content and face validity of the instrument. The feedback and discussion helped improve the appropriateness of the questionnaire. Second, the improved questionnaire was pilot-tested on 10 exporters. The pilot test was to ensure that the questions were clear and easily understood by the respondents. In general, it was observed that the selected respondents had no major difficulties in filling out the questionnaire. However, a few minor changes were made to the questionnaire to improve its format and facilitate analysis. The time taken to complete the questionnaire ranged from 20 to 30 minutes. To avoid any form of bias, the 10 respondents involved in the pilot survey were excluded from the final survey.

The questionnaire comprises 4 sections. Part 1 profiles the firm and its major export markets. Part 2 details the stringency of NTMs (public measures only) in the different export markets. Part 3 details the stringency of private measures in different export markets. Part 4 takes into account the response strategies of the exporters faced with NTMs. The paper, however, only draws on the information provided in Parts 1 and 2 of the questionnaire. For Part 2, the questionnaire follows the UNCTAD (2013) classification of NTMs for 15 types of import measures (destination countries), which include technical (Chapters A - C) and non-technical (Chapters D - O) measures. Technical measures comprise SPS (Chapter A), TBT (Chapter B) and pre-shipment inspection and other formalities (Chapter $\mathrm{C}$ ). Non-technical measures include the following 12 measures: contingent trade protective measures (Chapter D); non-automatic licensing, quotas, prohibitions and quantity control measures other than for SPS or TBT reasons (Chapter E); price-control measures, including additional taxes and charges (Chapter F); finance measures (Chapter G); measures affecting competition (Chapter $\mathrm{H})$; trade-related investment measures (Chapter I); distribution restrictions (Chapter J); restrictions on post-sales services (Chapter $\mathrm{K}$ ); subsidies (Chapter L); government procurement restrictions (Chapter $\mathrm{M}$ ); intellectual property (Chapter $\mathrm{N}$ ); and rules of origin (ROOs) (Chapter O). The stringency of NTMs in Part 2 have been measured using a five point Likert scale, where 1 represents 'not stringent' to 5 for 'very stringent.'

Further, interviews were conducted to verify some of the results obtained from the survey. A total of 20 exporters were interviewed. These exporters comprised establishments of different sizes: 11 small-sized firms, 6 medium-sized firms and 3 largesized firms. In terms of the type of business, the exporters that were interviewed were mainly resource-based firms (65 percent), and the remaining 35 percent were nonresource-based firms.

\subsection{Model Specification and Empirical Strategy}

The following model explains the stringency of NTMs on Malaysian exports, in general, and by major export destinations. The control variables included are firm type, ownership, firm experience and firm size, accounting for the relevant characteristics 
that explain firms' export behaviour (see Bernard \& Jensen, 2004; Roberts \& Tybout, 1997).

$$
X=\alpha+\beta_{1} \text { Type }+\beta_{2} \text { Own }+\beta_{3} \operatorname{Exp}+\beta_{4} \text { Size }+\beta_{5} \text { SNTM }
$$

where

$X=$ export level (proportion of exports to sales)

Type $=$ firm type (resource or non-resource-based firm)

Own = firm ownership (foreign and local)

Exp $=$ firm experience (based on years in operation: $<5$ years, 5-10 years and $>10$ years)

Size $=$ firm size (small, medium and large)

SNTM = stringency of NTMs (overall, by type and export destination)

The multinomial logistic model is used to estimate the stringency of NTMs on the level of exports ${ }^{7}$ (export intensity, proportion of exports to sales), as the dependent term is a nominal variable with four export levels. Thus, equation (1) is examined for the three export levels, where $X_{1}=$ less than 25 percent; $X_{2}=26-50$ percent; $X_{3}=51$ 75 percent. The reference group is $X_{4}=$ more than 75 percent. The stringency of NTMs are also considered for the major export destinations of Malaysia, the United States (US), the European Union (EU), Japan, China and the Association of Southeast Asian Nations (ASEAN).

The core variable in equation (1), SNTM, is measured by type of NTM (technical and non-technical) and by major export destinations (US, EU, Japan and ASEAN). SNTM is based on the exporters' perceptions of the stringency of the specific NTM. It is calculated as a simple average of the stringency perceptions (scores) of NTMs. The argument here is that a specific type of NTM at a specific export market is perceived to be stringent if it bears a significant impact on production/transaction costs (resources and capacities) (De, 2011; Portugal-Perez, Reyes, \& Wilson, 2010) and/or delivery (Francois, Manchin, \& Norberg, 2011), thereby impeding or reducing exports.

The grouping of firms is based on national classification systems for the manufacturing sector. Resource-based firms include food, beverages and tobacco, wood products, paper products, chemicals and related industries, plastic products, petroleum products, rubber products and non-metallic mineral products. Non-resource based firms refer to textiles and apparel, basic metal, machinery, electrical and electronics, transport equipment and others. In terms of firm size, small firms refer to establishments with full-time employees of 5-74 persons, medium-sized firms are those with 75199 employees and large firms are those with 200 or more full-time employees. Though data on sales turnover is also collected from the survey, firm size, as employed in the study is solely based on the number of employees. From the ownership perspective, foreign owned firms are those with more than 50 percent foreign equity. There is no standard classification for firm experience or firm age. Therefore the firms are classified into less than 5-years in operation, 5-10 years and more than 10 years in operation.

This measure of export behaviour has been well established (Katsikeas, Leonidou, \& Morgan, 2000), and firms are more comfortable to share information on export proportion to sales than net profits (Marandu, 2008). 
Firms that are more than 10 years in existence are considered to be established or mature firms, as per the literature.

\subsection{Diagnostic Tests}

Three diagnostics tests have been performed. First, is the deviance, or -2 log likelihood (-2LL) statistic. The deviance is basically a measure of how much unexplained variation there is in a logistic regression model; the higher the value, the less accurate the model. A model fit requires the value to be significant. It would suggest that there is a relationship between the dependent variable and combination of independent variables. The second test is the Pseudo-square. According to McFadden (1974), values of Pseudo-square ranging from 0.2 to 0.4 are considered 'highly satisfactory.' With regard to the sample size, for multinomial logistic regression, a minimum of 10 cases per independent variable is required. The final test refers to the question of reliability, which measures the overall consistency of the items in the questionnaire. It is measured on the same scale as a correlation coefficient, and its value lies between 0 (no internal consistency) and 1 (perfect internal consistency). Cronbach's alpha is the most common measure of internal consistency ('reliability'). As a rule of thumb, internal consistency is considered acceptable if the alpha value exceeds 0.7.

The model is considered fit as it passes the required diagnostic tests. More importantly, the Cronbach alpha is 0.975 , which indicates a high level of internal consistency for the scale with the sample size of 143 . The likelihood ratio tests are presented in Table 1. It shows that the stringency of NTMs is significantly related to the effect (export level). The control variables used in the analysis are also found to be significant, suggesting that each variable contributes to the model.

\section{Results and Discussion}

\subsection{Sample Profile}

The sample of firms surveyed include 38 percent of resource-based firms, while the remaining 62 percent constitute non-resource based firms. The sample is fairly representative of the structure of trade in Malaysia as resource-based firms make up approximately 43 percent of the total number of establishments. More importantly,

Table 1. Likelihood ratio tests

\begin{tabular}{lccccc}
\hline Effect & \multicolumn{2}{c}{ Model fitting criteria } & & \multicolumn{3}{c}{ Likelihood ratio tests } \\
\cline { 2 - 2 } & -2 log likelihood of reduced model & & Chi-square & df & Sig. \\
\hline Firm type & 174.038 & & 14.705 & 3 & .002 \\
Firm ownership & 168.082 & & 8.749 & 3 & .033 \\
Firm experience & 174.128 & & 14.795 & 6 & .022 \\
Firm size & 190.685 & & 31.352 & 6 & .000 \\
NTM stringency & 172.368 & 13.035 & 3 & .005 \\
\hline
\end{tabular}

Note: The reduced model is equivalent to the final model because omitting the effect does not increase the degrees of freedom (df). 
Table 2. Sample of firms

\begin{tabular}{|c|c|c|}
\hline Firm characteristics & Sample & Population \\
\hline \multicolumn{3}{|l|}{ Firm type } \\
\hline Resource & 38.0 & 42.9 \\
\hline Non-resource & 62.0 & 57.1 \\
\hline \multicolumn{3}{|l|}{ Firm ownership } \\
\hline Malaysian & 87.4 & 26.6 \\
\hline Foreign & 12.6 & 73.4 \\
\hline \multicolumn{3}{|l|}{ Firm experience (years in operation) } \\
\hline Less than 5 years & 18.9 & n.a. \\
\hline $5-10$ years & 20.3 & n.a. \\
\hline More than 10 years & 60.8 & n.a. \\
\hline \multicolumn{3}{|l|}{ Firm size } \\
\hline Small & $62.5\}$ & \\
\hline Medium & $34.4\}$ & 93.3 \\
\hline Large & 3.1 & 6.7 \\
\hline
\end{tabular}

Notes: (1) The data reflects the share in total firms (\%). (2) The population refers to national-level statistics for manufacturing. (3) n.a. - not available.

Source: (1) Sample data are obtained from the survey of the study. (2) Population data are derived from the Annual Survey of Manufacturing Industries, Malaysia.

many of the firms surveyed are experienced firms, with more than 10 years in operation. The responses given regarding the stringency of NTMs can therefore be taken with confidence given that these are mature firms. The other remaining characteristics $^{8}$ of the sampled firms are presented in Table 2.

All the firms surveyed cite one or more of the selected export destinations (US, EU, Japan, China and ASEAN) as their major market(s). Further, all firms have encountered different NTMs in those markets. The incidence of NTMs faced by the exporters are presented in Figure 1. With the exception of subsidies, all firms encountered the other remaining 14 NTMs. Pre-shipment inspection and formalities constitute the highest frequency of NTMs encountered by the firms, followed by TBT and ROOs (see also OECD, 2005). The detailed descriptive statistics (not reported here) also show that technical measures (Chapters A, B and C), form the highest incidence of NTMs faced by both resource- and non-resource based firms.

\subsection{Stringency of NTMS}

The parameter estimates for equation (1) are presented in Table 3. It shows that firms that export less than 75 percent of their sales are more likely to find NTMs to be stringent relative to the reference group, which are firms with export intensity of more

8 Though most of the firms surveyed are local-firms, and therefore not reflective of the ownership structure of the Malaysian manufacturing sector, this does not limit the study. In fact, the perceptions of stringency of NTMs by local firms are important for the government to link these businesses directly with international markets. 


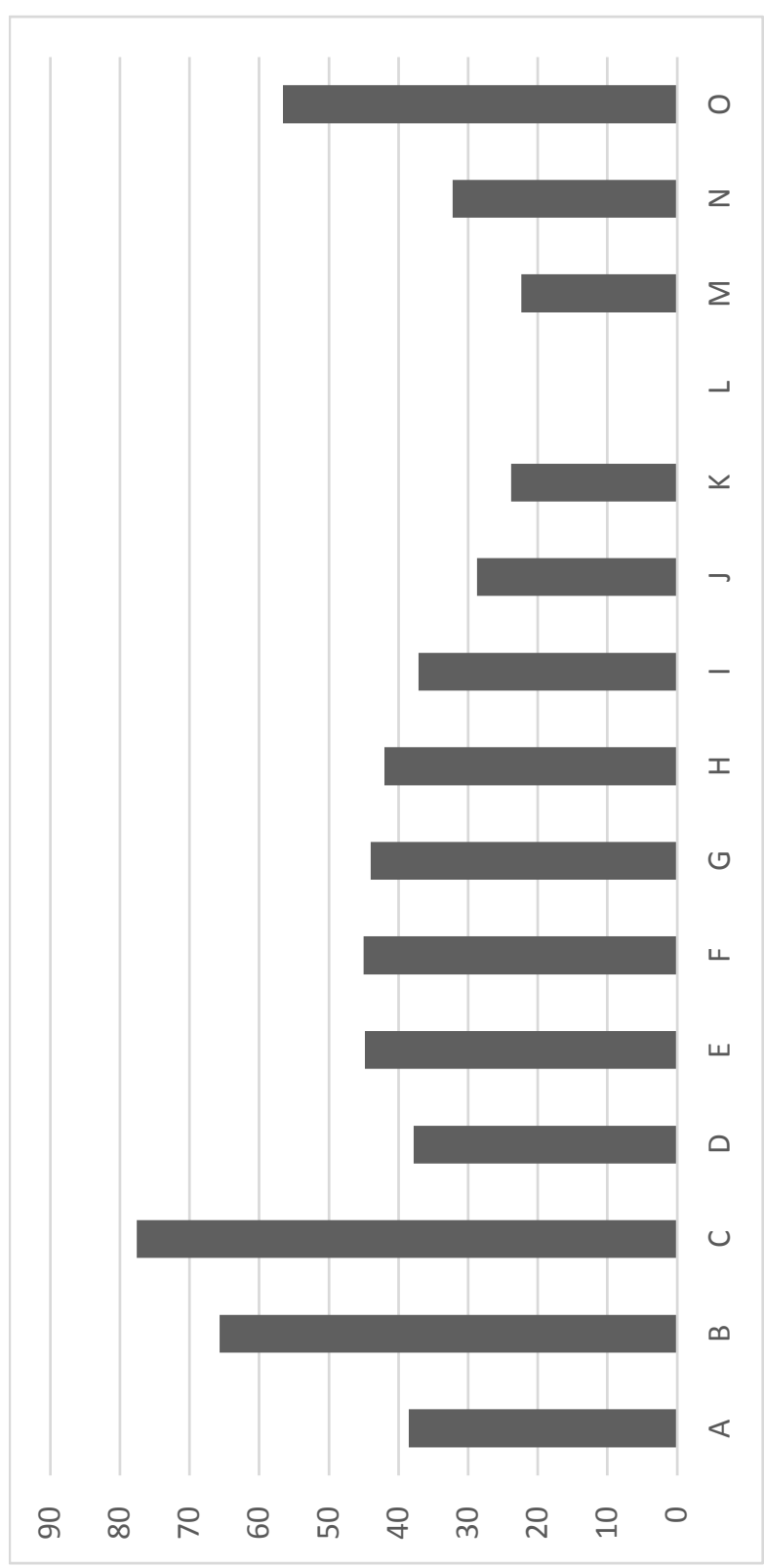

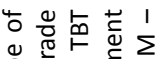

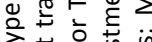

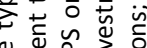

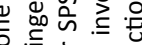

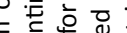

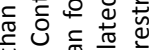

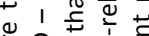

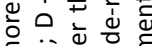
$\varepsilon$ ì 过 О: 还 ฯ है뉸 ¿ ऐ

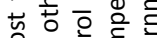

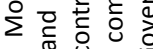
ن 要号营

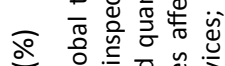
u $\sum \subseteq \subseteq$ वे 乏 ठ प

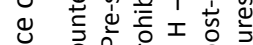
व ठำ 효 은 ट

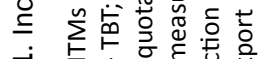

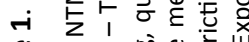
ข

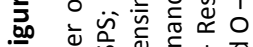

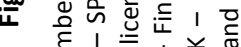

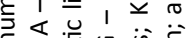

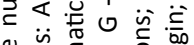

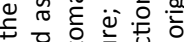
ᄃ ठ웡 ऽ

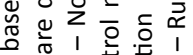

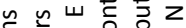
है ญัँ

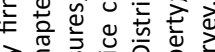

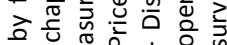
๗®

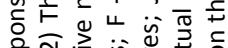

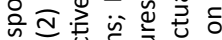

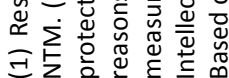
苍雚 
Stringency of Non-Tariff Measures in Partner Countries: Perceptions of Malaysian Exporters

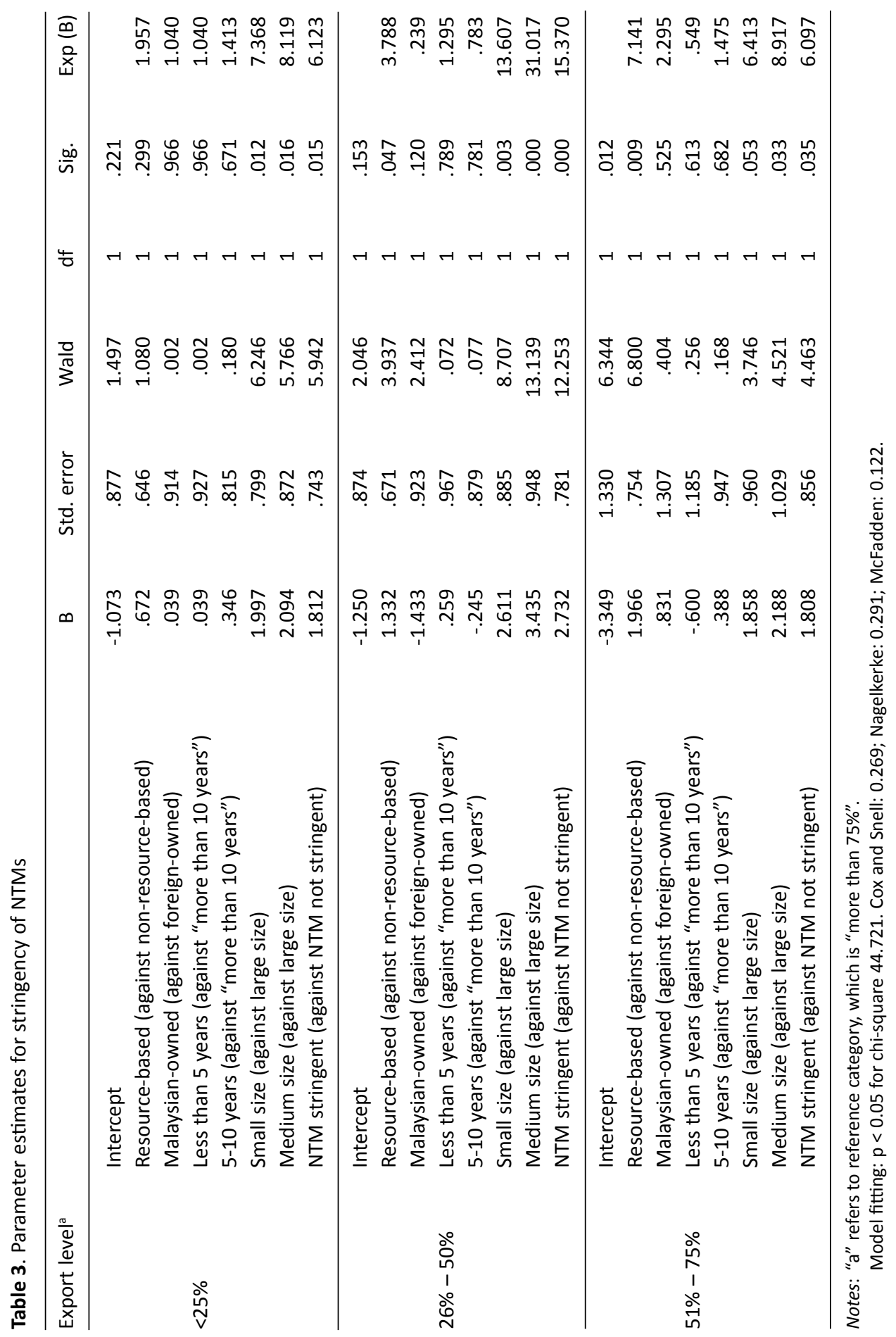




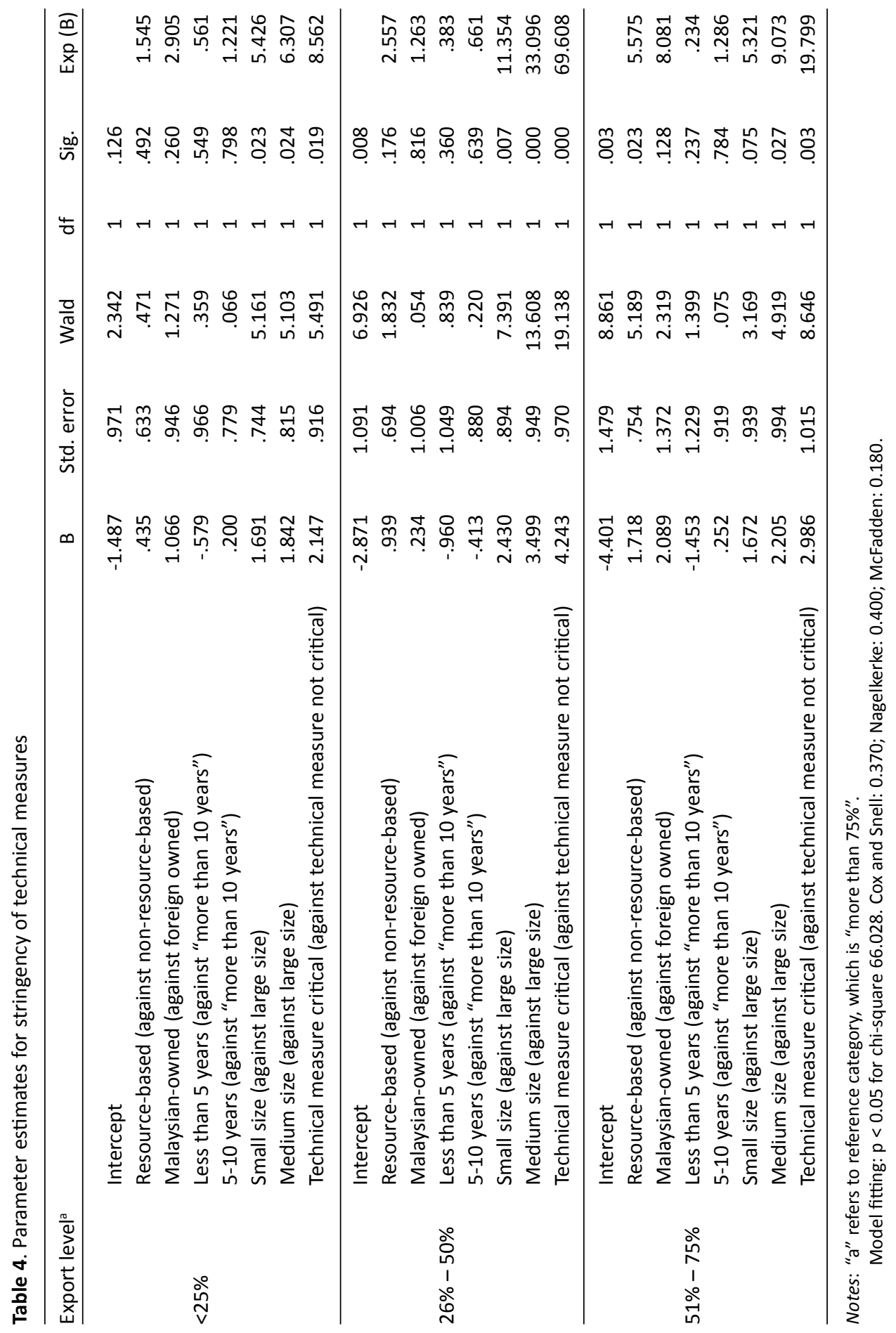


than 75 percent. The result supports the notion that firms that are more dependent on external markets (export levels of more than 75 percent) are less likely to find NTMs to be stringent, as their internationalisation exposure places them in a better position to meet the standards and requirements in the export markets and also address any related compliance costs (see also Nixson \& Wignaraja, 2004; Jaffee, 2005; Maertens \& Swinnen, 2009).

Firm type (resource-based firms) and firm size (small and medium firms) are found to significantly explain export behaviour, while ownership and experience ${ }^{9}$ do not seem to matter. Resource-based industries such as food products generally attract a higher level of regulations, namely for food safety or food security reasons (Duval \& Feyler, 2016; Chaponniere \& Lautier, 2016). Through the interviews, it was also made clear that NTMs are indeed an issue for the small-sized firms, relative to the medium and large firms, as they do not enjoy economies of scale, and they incur high and recurrent compliance costs (see also Henson \& Heasman, 1998; Loader \& Hobbs, 1999; Anders \& Caswell, 2009; Pasadilla \& Liao, 2007; Bhandari \& Maiti, 2007).

To further identify the stringency of different measures, the analysis is repeated for technical and non-technical measures. The reason for this disaggregated analysis is due to the high frequency of technical measures in global trade (Nicita \& Gourdon, 2013; OECD, 2005; Wilson, 2007; Otsuki et al., 2001) and the high compliance costs related to technical measure requirements (Moise \& Le Bris, 2013). The results are reported in Table 4.

The disaggregated analysis in Table 4 produces results that are robust to the overall NTMs in Table 3. The perceived stringency of technical measures is again more likely for firms that export 75 percent and below compared to the reference group.

\subsection{Stringency of NTMs by Export Destinations}

To distinguish the stringency of NTMs across export destinations for Malaysian goods, the core markets, US, EU, Japan, China and ASEAN are each interacted with the NTM stringency variable (STNM) of equation (1). Table 5 presents a summary of the results. ${ }^{10}$

Generally, all firms that export below 75 percent are more likely to find NTMs to be stringent in most major export destinations. The only exception is the Chinese and ASEAN markets, where only firms with export intensities of 50 percent and below perceive NTMs to be stringent in the regional markets. It is not surprising to note that firms with export intensities of 75 percent and below find the advanced US, EU and Japan markets to be restrictive. From the interviews, it is noted that though the EU has less number of NTMs relative to the US and Japan markets, the EU measures are restrictive (see also Fliess \& Kim, 2008).

Though Malaysia is part of ASEAN and the ASEAN-China Free Trade Agreement (ACFTA), NTMs in ASEAN and China are still perceived stringent to specific group of

\footnotetext{
9 The relationship between firm age and exports is ambiguous. Though older firms may be more experienced with international trade, newer firms may use relatively modern technology to increase productivity and product quality.

10 The detailed results for each market are not reported here for want of space.
} 
Table 5. Summary results of stringency of NTMs by export destinations

\begin{tabular}{|c|c|c|c|c|c|c|}
\hline Export levels $^{\mathrm{a}}$ & B & Std. error & Wald & df & Sig. & $\operatorname{Exp}(B)$ \\
\hline \multicolumn{7}{|l|}{ US } \\
\hline$<25 \%$ & 2.672 & 1.181 & 5.120 & 1 & .024 & 14.466 \\
\hline $26 \%-50 \%$ & 2.635 & 1.181 & 4.976 & 1 & .026 & 13.939 \\
\hline $51 \%-75 \%$ & 2.611 & 1.258 & 4.304 & 1 & .038 & 13.610 \\
\hline \multicolumn{7}{|l|}{ EU } \\
\hline$<25 \%$ & 1.713 & .714 & 5.758 & 1 & .016 & 5.544 \\
\hline $26 \%-50 \%$ & 1.856 & .729 & 6.483 & 1 & .011 & 6.401 \\
\hline $51 \%-75 \%$ & 1.598 & .806 & 3.928 & 1 & .047 & 4.941 \\
\hline \multicolumn{7}{|l|}{ Japan } \\
\hline$<25 \%$ & 1.429 & .751 & 3.620 & 1 & .057 & 4.176 \\
\hline $26 \%-50 \%$ & 2.861 & .838 & 11.670 & 1 & .001 & 17.487 \\
\hline $51 \%-75 \%$ & 1.711 & .704 & 5.903 & 1 & .015 & 5.532 \\
\hline \multicolumn{7}{|l|}{ China } \\
\hline$<25 \%$ & 1.707 & .734 & 5.402 & 1 & .020 & 5.510 \\
\hline $26 \%-50 \%$ & 1.968 & .754 & 6.805 & 1 & .009 & 7.156 \\
\hline $51 \%-75 \%$ & .341 & .893 & .146 & 1 & .703 & 1.406 \\
\hline \multicolumn{7}{|l|}{ ASEAN } \\
\hline$<25 \%$ & 1.700 & .576 & 8.703 & 1 & .003 & 5.473 \\
\hline $26 \%-50 \%$ & 1.187 & .585 & 4.117 & 1 & .042 & 3.276 \\
\hline $51 \%-75 \%$ & 1.080 & .663 & 2.653 & 1 & .103 & 2.945 \\
\hline
\end{tabular}

Note: a Reference category is "more than $75 \%$ ".

firms with export intensities of less 50 percent and below. This could be attributed to the concern raised by Cadot, Munadi and Ing (2015) that the region suffers from lack of information on NTMs as they are not transparent, which then results in substantial price-raising effect of NTMs on exporters. NTBs, namely non-automatic licensing, technical regulations and quality standards, are found to continue to constitute serious impediments to intra-regional trade and pose a real concern for ASEAN to achieve a single market and production base (Plummer, Petri, \& Zhai, 2014; Das, 2012; Shepherd, 2010). In the case of China, big surges in the usage of NTMs have been recently noted (Heal \& Palmioli, 2015). The feedback from the interviews further indicate that the markets of ASEAN and China pose similar hurdles for Malaysian exporters in the form of cumbersome customs procedures.

By type of NTM, the findings on stringency are also detailed out for each export market in Table 6 . The results are robust to the overall findings on NTMs by export destinations in Table 5. Through the interviews with the selected firms, all agree that technical measures are more critical than non-technical measures. This concurs with the findings by Fugazza (2013), who posited that technical measures, especially the TBT and SPS, pose a concern to developing countries. He noted that on average, approximately 30 percent and 15 percent of products traded by developing countries are likely to face the brunt of TBT and SPS measures, respectively. 
Table 6. Summary results of stringency of technical measures by export market

\begin{tabular}{|c|c|c|c|c|c|c|}
\hline Export Level ${ }^{a}$ & B & Std. error & Wald & $d f$ & Sig. & $\operatorname{Exp}(B)$ \\
\hline \multicolumn{7}{|l|}{ US } \\
\hline$<25 \%$ & 1.446 & .758 & 3.642 & 1 & .056 & 4.246 \\
\hline $26 \%-50 \%$ & 3.612 & .828 & 19.017 & 1 & .000 & 37.040 \\
\hline $51 \%-75 \%$ & 1.767 & .876 & 4.073 & 1 & .044 & 5.855 \\
\hline \multicolumn{7}{|l|}{ EU } \\
\hline$<25 \%$ & 1.385 & .753 & 3.382 & 1 & .066 & 3.994 \\
\hline $26 \%-50 \%$ & 3.590 & .825 & 18.931 & 1 & .000 & 36.237 \\
\hline $51 \%-75 \%$ & 2.198 & .867 & 6.419 & 1 & .011 & 9.004 \\
\hline \multicolumn{7}{|l|}{ Japan } \\
\hline$<25 \%$ & 1.610 & .783 & 4.229 & 1 & .040 & 5.005 \\
\hline $26 \%-50 \%$ & 3.582 & .839 & 18.247 & 1 & .000 & 35.955 \\
\hline $51 \%-75 \%$ & 2.249 & .889 & 6.397 & 1 & .011 & 9.480 \\
\hline \multicolumn{7}{|l|}{ China } \\
\hline$<25 \%$ & 1.767 & .725 & 5.938 & 1 & .015 & 5.853 \\
\hline $26 \%-50 \%$ & 2.049 & .739 & 7.685 & 1 & .006 & 7.759 \\
\hline $51 \%-75 \%$ & .397 & .880 & .204 & 1 & .652 & 1.488 \\
\hline \multicolumn{7}{|l|}{ ASEAN } \\
\hline$<25 \%$ & 1.648 & .707 & 5.440 & 1 & .020 & 5.197 \\
\hline $26 \%-50 \%$ & 1.509 & .728 & 4.297 & 1 & .038 & 4.521 \\
\hline $51 \%-75 \%$ & .354 & .874 & .164 & 1 & .685 & 1.425 \\
\hline
\end{tabular}

Note: a Reference category is "more than 75\%."

Further, through the interviews, many firms also pointed out that the EU and Japan have strict customs procedures relative to the US. For example, Liu and Yue (2009) reported that the strict customs procedures in Japan for cut flowers has become a barrier for many exporters, including Malaysia. Through discussion with the exporters, it was indeed surprising to note that many of the firms voiced their displeasure in customs procedures, even within the ASEAN region. This is also corroborated by the EUASEAN Business Council (2015) that most ASEAN countries' customs procedures are still trade prohibitive. The Council noted that non-transparent and inconsistent application of customs procedures amongst member countries continue to impede the free flow of goods, despite the 2005 ASEAN Single Window (ASW) to expedite cargo clearance. It is also further reported than unstandardised, lengthy and complex customs procedures in ASEAN countries continue to weigh heavily on small- and medium-sized firms' trade flow (see also OECD, 2005; Wilson, 2007; Nordas, Pinali and Grosso, 2006; and World Bank, 2009 for similar arguments on customs procedures). This is not surprising as the ASW initiative is still very much a work in progress. It is not full-fledge as it depends on the completion of the National Single Window (NSW) initiative of each ASEAN member. To date, only five (Malaysia, Indonesia, Singapore, Thailand and Vietnam) member countries have completed the NSW and integrated with the ASW, yet the administrative readiness of these countries is still questionable (Benjelloun, Pantastico, \& Wong, 2012). 
Through the interviews, the small and medium firms pointed out that the critical issue in advanced markets also relate to private measures, which are often neglected in the NTM discussions. In many cases, private measures or standards are considered more stringent than public standards. There has been a rise in private measures or standards globally, introduced by private organisations and institutions (Henson \& Hooker, 2001; Henson, 2004; Fulponi, 2007), as firms that aim to differentiate their products in international markets comply with private standards to have product safety and quality attributes endorsement (see also Henson \& Reardon, 2005). The EU, in particular, has accepted these stricter private standards as de facto minimum that the businesses must comply. Some examples of private measures in the EU include the regulations on genetically modified organism (Vigani \& Olper, 2014), private standards imposed by organisations like the British Retail Consortium (BRC) or Global Partnership for Good Agriculture Practices (GLOBALGAP) and the Global Food Safety Initiative (GFSI) for food safety and or sustainability reasons (Fulponi 2007). The compliance costs of these certifications can be somewhat substantial for the small players globally, as several studies (Nishitani, 2009; Arimura, Hibiki, \& Katayama, 2008; King, Lenox, \& Terlaak, 2005) have shown that there is a positive correlation between firm size and certification.

\section{Conclusion}

This study confirms that NTMs pose a disproportionate effect on Malaysian exporters; NTMs are likely to pose challenges to a particular group of exporters in Malaysia. Overall, as reflected in the findings, Malaysian firms that export less than 75 percent of their total sales, find NTMs in the major export markets as stringent. Firm size, relative to firm ownership and firm age, explains the export behaviour of Malaysian firms. Conversely, export intensive and larger firms that generally have exposure and capabilities to manage and comply with NTM requirements in export markets, do not find NTMs an issue.

Technical measures, customs procedures and other formalities, TBTs and SPS, are reported to be stringent for the affected group of exporters (export intensities of below 75 percent). From the interviews, firms from the resource-based industry (namely the food sector) singled out high compliance costs in major markets. The food sector comprises mainly small and medium enterprises. These firms are faced with fixed costs, which do not vary with the amount traded, to comply with standards in the advanced markets such as the EU. Unlike large firms, these small-sized exporters are not able to spread their fixed costs over their small sales volume. Further, many of the small firms also added that private standards are also critical for entry into the advanced markets.

By market destinations, a larger group of exporters (firms with export intensities of below 75 percent) perceived the advanced markets of EU, US and Japan as stringent relative to China and ASEAN. However, many firms expressed their problems with customs procedures and formalities in all major markets. Despite the streamlining of customs procedures within the region, ASEAN countries continue to struggle to have a standardised environment for businesses, especially for the small and medium firms to be competitive (The Star, 1 June 2015). 
The findings of the study have important implications to guide the policy debate on NTMs. First, the small and medium resource-based enterprises, with less exposure to international trade, should be the target group of policymakers for providing assistance in complying with global standards and regulations. Second, technical measures, such as customs procedures and formalities and TBTs, should be given priority by the relevant stakeholders in streamlining and harmonising these measures to conform to global standards and regulations. In this regard, a full-fledged ASW is required for speedier customs clearance in the region. This demands serious commitment from each member country to implement their NSW; a pre-requisite for ASW to be fully effective. Third, private measures, particularly for resource-based firms, should also be factored in the negotiations with trade partners at the outset, to facilitate trade. Fourth, the implementation status of the harmonisation procedures at the regional level should be given sufficient attention by policymakers, as this will provide the platform to benchmark regional standards with global requirements.

\section{References}

Anders, S.M., \& Caswell, J.A. (2009). Standards as barriers versus standards as catalysts: Assessing the impact of HACCP implementation on U.S. seafood imports. American Journal of Agricultural Economics, 91(2), 310-321.

Arimura, T., Hibiki, A., \& Katayama, H. (2008). Is a voluntary approach an effective environmental policy instrument? A case for environmental management systems. Journal of Environmental Economics and Management, 55(3), 281-295.

Athukorala, P., \& Jayasuriya, S. (2003). Food safety issues, trade and WTO rules: A developing country perspective. World Economy, 26(9), 1395-1416.

Benjelloun, R., Pantastico, D., \& Wong, M. (2012). Cross-border e-trade: The ASEAN Single Window (Trade and Investment Division Working Paper No. 03/12). Bangkok: Economic and Social Commission for Asia and the Pacific.

Bernard, J., \& Jensen, B. (2004). Why some firms export? Review of Economics and Statistics, 86(2), 561-569.

Bhandari, A., \& Maiti, P. (2007). Efficiency of Indian manufacturing firms: Textile industry as a case study. International Journal of Business Economics, 6(1), 71-88.

Bao, X., \& Qiu, L.D. (2012). How do technical barriers to trade influence trade? Review of International Economics, 20(4), 691-706.

Cadot, O., \& Ing, L.Y. (2015). Non-tariff measures and harmonisation: Issues for the RCEP (ERIA Discussion Paper Series No. 2015-61). Jakarta: Economic Research Institute for ASEAN and East Asia.

Cadot, O., Munadi, E., \& Ing, L.Y. (2015). Streamlining NTMs in ASEAN: The way forward. Asian Economic Papers, 14(1), 35-70.

Chaponniere, J-R, \& Lautier, M. (2016). By chance or by virtue? The regional economic integration process in Southeast Asia. In Bruno Jetin \& Mia Mikic (Eds.), ASEAN Economic Community: A model for Asia-wide regional integration? (pp. 33-57). UK: Palgrave MacMillan.

Chen, M.X., Otsuki, T., \& Wilson, J.S. (2006). Do standard matters for export success? (World Bank Policy Research Working Paper 3809). Washington DC: World Bank.

Chen, M.X., Wilson, J.S., \& Otsuki, T. (2008). Standards and export decisions: Firm-level evidence from developing countries. Journal of International Trade \& Economic Development, 17(4), 501-523.

Cox, D.R., \& Snell, E.J. (1989). Analysis of Binary Data (2nd ed.). UK: Chapman \& Hall. 
Das, S.B. (2012). Achieving the ASEAN Economic Community 2015. Singapore: ISEAS-Yusof Ishak Institute.

De, P. (2011). Why is trade at borders a costly affair in South Asia? An empirical investigation. Contemporary South Asia, 19(4), 441-464.

Disdier, A-C., Fekadu, B., Murillo, C., \& Wong, S.A. (2008). Trade effects of SPS and TBT measures on tropical and diversification products (ICTSD Paper No. 12). Geneva: International Centre for Trade and Sustainable Development.

Disdier, A.C., Fontagne, L., \& Mimouni, M. (2008). The impact of regulations on agricultural trade: Evidence from the SPS and TBT agreements. American Journal of Agricultural Economics, 90(2), 336-350.

Duval, Y., \& Feyler, E. (2016). Intra- and extra-regional trade costs of ASEAN economies: Implications for Asian regional integration. In Bruno Jetin \& Mia Mikic (Eds.), ASEAN Economic Community: A model for Asia-wide regional integration? (pp. 153-172). UK: Palgrave MacMillan.

EU-ASEAN Business Council. (2015). Realising the potential of ASEAN. Retrieved from http://euasean.eu/wp-content/uploads/2015/07/Realising-the-Potential-of-ASEAN.pdf

Fliess, B., \& Kim, J. (2008). Non-tariff barriers facing trade in selected environmental goods and associated services. Journal of World Trade, 42(3), 535-562.

Fontagne, L., von Kirchbach, F., \& Mimouni, M. (2005). An assessment of environment-related trade barriers. World Economy, 28(10), 1417-1439.

Francois, J., Manchin, M., \& Norberg, H. (2011). European perspectives on NTM and tariff liberalization (ESRI Discussion Paper Series No. 265). Tokyo: Economic and Social Research Institute.

Fugazza, M. (2013). The economics behind non-tariff measures: Theoretical insights and empirical evidence (Policy Issues in International Trade and Commodities Studies Series No. 57). Geneva: United Nations.

Fugazza, M., \& Maur, J-C. (2008). Non-tariff barriers in computable general equilibrium modelling (UNCTAD Policy Issues in International and Commission Study Series No. 38). Geneva: United Nations.

Fulponi, L. (2007). The globalization of private standards and the agri-food system. In J.F.M. Swinnen (Ed.), Global supply chains, standards and the poor (pp. 5-18). England: Centre for Agricultural Bioscience International.

Gebrehiwet, Y., Ngqangweni, S., \& Kirsten, J.F. (2007). Quantifying the trade effect of sanitary and phytosanitary regulations of OECD countries on South African food exports. Agrekon, 46(1), 23-39.

Hanif, A. (2013). Non-tariff barriers in Malaysia. United States: LAP LAMBERT Academic Publishing.

Heal, A., \& Palmioli, G. (2015). Trade and non-tariff measures: Impacts in the Asia-Pacific region. Bangkok: Economic and Social Commission for Asia and the Pacific.

Henson, S. (2004). Standards and trade: An overview. Department of Agricultural Economics \& Business, University of Guelph, Ontario, Canada. Retrieved from siteresources.worldbank. org/INTRANETTRADE/Resources/Topics/Accession/Standards\&TradeOverview_Eng.doc

Henson, S., \& Heasman, M. (1998). Food safety regulation and the firm: Understanding the compliance process. Food Policy, 23(1), 9-23.

Henson, S., \& Jaffee, S. (2004). Standards and agro-food exports from developing countries: Rebalancing the debate (World Bank Policy Research Working Paper No. 3348). Washington DC: World Bank.

Henson, S.J., \& Hooker, N.H. (2001). Private sector mangement of food safety: Public regulation and the role of private controls. International Food and Agribusiness Management Review 4, 7-17.

Henson, S.J., \& Reardon, T. (2005). Private agri-food standards: Implication for food policy and the agri-food system. Food Policy, 30(3), 241-253. 
lacovone, L. (2005). The analysis and impact of sanitary and phytosanitary measures. Integration and Trade Journal, 9(22), 97-140.

Jaffee, S.M. (2005). Delivering and taking the heat: Indian spices and evolving product and process standards (Agricultural and Rural Development Discussion Paper No. 19). Washington DC: World Bank.

Jakubiak, M., Maliszewska, M., Orlova, I., Rokicka, M., \& Varyschuk, V. (2006). Non-tariff barriers in Ukrainian exports to the EU (CASE Network Reports No. 68/2006). Warsaw: Center for Social and Economic Research.

Jayasekhar, S., \& Kumar, C.N. (2010). Compliance, competitiveness and market access: A study on Indian seafood industry (CDS Working Paper No. 422). Kerala: Centre for Development Studies.

Katsikeas, C.S., Leonidou, L.C., \& Morgan, N.A. (2000). Firm-level export performance assessment: Review, evaluation and development. Journal of the Academy of Marketing Science, 28(4), 493-511.

Kee, H.L., Nicita, A., \& Olarreaga, M. (2009). Estimating trade restrictiveness indices. The Economic Journal, 119 (January), 172-199.

King, A., Lenox, M., \& Terlaak, A. (2005). The strategic use of decentralized institutions: Exploring certification with the ISO 14001 management standard. Academy of Management Journal, 48(6), 1091-1106.

Korinek, J., Melatos, M., \& Rau, M-L. (2008). A review of methods for quantifying the trade effects of standards in the agri-food sector (OECD Trade Policy Working Paper No. 79). Paris: Organization for Economic Co-operation and Development.

Liu, L., \& Yue, C. (2009). Non-tariff barriers caused by SPS measures and customs procedures with product quality changes. Journal of Agricultural and Resources Economics, 34(1), 196-212.

Loader, R., \& Hobbs. J.E. (1999). Strategic responses to food safety regulation. Food Policy, 24(6), 685-706.

Maertens, M., \& Swinnen, J.F.M. (2009). Trade, standards and poverty: Evidence from Senegal. World Development, 37(1), 161-178.

Marandu, E.E. (2008). Strategy factors associated with the export performance of manufacturing firms. Journal of Business in Developing Nations, 11, 33-76.

Masakure, O., Henson, S., \& Cranfield, J. (2009). Standards and export performance in developing countries: Evidence from Pakistan. Journal of International Trade \& Economic Development, 18(3), 395-419.

Maskus, K.E., Wilson, J.S., \& Otsuki, T. (2001). Quantifying the impact of technical barriers to trade: A framework of analysis (Policy Research Working Paper No. 2512). Washington DC: World Bank.

McFadden, D. (1974). Conditional logit analysis of qualitative choice behaviour. In P. Zarembka (Ed.), Frontiers in Econometrics (pp. 105-142). New York: Academic Press.

Mehta, R., \& George, J. (2003). Processed food products exports from India: An exploration with SPS regime. New Delhi: India Habitat Centre. Retrieved from https://digitalcollections.anu. edu.au/bitstream/1885/41962/1/aciar_2003_mehta_george.pdf

Moise, E., \& Le Bris, F. (2013). Trade costs - what have we learnt: A synthesis report (OECD Trade Policy Paper No. 150). Paris: Organization for Economic Cooperation and Development.

Moenius, J. (2004). Information versus product adaptation: The role of standards in trade. Retrieved from http://papers.ssrn.com/sol3/papers.cfm?abstract_id=608022

Nagelkerke, N.J.D. (1991). A note on a general definition of the coefficient of determination. Biometrika, 78(3), 691-692.

Nicita, A., \& Gourdon, J. (2013). A preliminary analysis on newly collected data on non-tariff measures (Policy Issues in International Trade and Commodities Studies Series No. 53). Geneva: United Nations. 
Nishitani, K. (2009). An empirical study of the initial adoption of ISO 14001 in Japanese manufacturing. Ecological Economics, 68(3), 669-679.

Nixson, F., \& Wignaraja, G. (2004). Non-tariff measures, technological capability building and exports in India's pharmaceutical firms. United Nations University, Netherlands. Retrieved from http://www.intech.unu.edu/publications/discussion-papers/2004-6.pdf

Noor Aini Zakaria. (2011). Trade barriers in forest industry between Malaysia and Europe (Unpublished PhD thesis). Agro ParisTech, Paris.

Nordas, H.K., Pinali, E., \& Grosso, M.G. (2006). Logistic and time as trade barrier (OECD Policy Working Paper No. 35). Paris: Organization for Economic Cooperation and Development.

OECD. (2003). Agricultural policies in OECD countries: Monitoring and evaluation. Paris: Author.

OECD. (2005). Analysis of non-tariff barriers of concern to developing countries (OECD Trade Policy Working Paper No. 16). Paris: Author.

Otsuki, T., Wilson, J.S., \& Sewadeh, M. (2001). Saving two in a billion: Quantifying the trade effect of European food safety standards on African exports. Food Policy, 26(5), 495-514.

Pasadilla, G.O., \& Liao, C.M. (2007). Non-tariff measures faced by Philippine agriculture exports in East Asia. Asian Journal of Agriculture and Development, 3(1\&2), 115-137.

Plummer, M.G., Petri, P.A., \& Zhai, F. (2014). Assessing the impact of ASEAN economic integration on labour markets (ILO Asia-Pacific Working Paper Series [September]), Bangkok: International Labour Organization.

Portugal-Perez, A., Reyes, J-D., \& Wilson, J.S. (2010). Beyond the information technology agreement: Harmonization of standards and trade in electronics. World Economy, 33(12), 1870-1897.

Rabiul, I., Shaharuddin, M.I., \& Chamhuri, S. (2010). Analyzing of trade barriers to timber trade policy. American Journal of Environmental Sciences, 6(1), 95-102.

Roberts, M., \& Tybout, J. (1997). An empirical model of sunk costs and the decision to export. American Economic Review, 87(4), 545-564.

Schlueter, S., Rau, M-L., Wieck, C., Humphrey, J., Colen, L., \& Heckelei, T. (2009). Analytical framework for the NTM-impact project (NTM Impact Working Paper No. 09/02). Brussels: European Commission. Retrieved from https://www.researchgate.net/publication/ 265561450_Analytical_framework_for_evaluating_the_productive_impact_of_cash_ transfer_programmes_on_household_behaviour_Methodological_guidelines_for_the_From_ Protection_to_Production_Project

Shepherd, B. (2010). Trade costs and facilitation in APEC and ASEAN: Delivering the goods? In Rising non-tariff protectionism and crisis recovery (pp. 93-110). Bangkok: United Nations Economic and Social Commission for Asia and the Pacific.

Swann, P., Temple, P., \& Shurmer, M. (1996). Standards and trade performance: The UK experience. Economic Journal, 106(438): 1297-1313.

The Star. (1st June 2015). Standardise ASEAN business environment. Retrieved from http://www. thestar.com.my/metro/smebiz/news/2015/06/01/standardise-asean-business-environment/

UNCTAD. (2013). Non-tariff measures to trade: Economic and policy issues for developing countries. Geneva: Author.

Vigani, M., \& Olper, A. (2014). GM-free private standards, public regulations of GM products and mass media. Environment and Development Economics, 19(6), 743-768.

Wilson, J.S., \& Otsuki, T. (2004). Standards and technical regulations and firms in developing countries: New evidence from a World Bank technical barriers to trade survey. Washington DC: World Bank. Retrieved from http://siteresources.worldbank.org/INTRANETTRADE/ Resources/Topics/Services/TBT_Data_Description.pdf

Wilson, N. (2007). Estimating the trade effect of certain customs and administrative procedures (Trade Policy Working Papers No. 42). Paris: Organization for Economic Cooperation and Development. 
World Bank. (2003). Standards and global trade: A voice for Africa. Washington, DC: Author.

World Bank. (2005). Food safety and agricultural health standards: Challenges and opportunities for developing exporters (Report No. 31027, Poverty Reduction \& Economic Management Trade Unit, Agriculture and Rural Development). Washington, DC: Author.

World Bank. (2008). A survey of non-tariff measures in the East Asia and Pacific region: Policy research report. Washington DC: Author.

World Bank. (2009). Doing business 2010: Reforming through difficult times. Washington DC: Author.

WTO. (2005). Exploring the links between trade, standards and the WTO. Geneva: Author.

WTO. (2012). Trade and public policies: A closer look at non-tariff measures in the 21st century. Geneva: Author. 
